2. Mair P, Hoermann C, Mair J, Margreiter J, Puschendorf B, Balogh D. Effects of a leucocyte depleting arterial line filter on perioperative proteolytic enzyme and oxygen free radical release in patients undergoing aortocoronary bypass surgery. Acta Anaesthesiol Scand. 1999;43:452-7.
3. Mihaljevic T, Tonz M, von Segesser LK, Pasic $\mathrm{M}, \mathrm{Grob} \mathrm{P}, \mathrm{Fehr} \mathrm{J}$ et al. The influence of leukocyte filtration during cardiopulmonary bypass on postoperative lung function. A clinical study. J Thorac Cardiovasc Surg. 1995;109:1138-45.

4. Whitaker DC, Newman SP, Stygall J, HopeWynne C, Harrison MJ, Walesby RK. The effect of leucocyte-depleting arterial line filters on cerebral microemboli and neuropsychological outcome following coronary artery bypass surgery. Eur $J$ Cardiothorac Surg. 2004;25:267-74.

doi:10.1016/j.jtcvs.2005.05.015

\title{
ON THE MOVE?
}

Don't miss a single issue of the journal! To ensure prompt service when you change your address, please photocopy and complete the form below.

Please send your change of address notification at least six weeks before your move to ensure continued service. We regret we cannot guarantee replacement of issues missed due to late notification.

\section{JOURNAL TITLE:}

Fill in the title of the journal here.

\section{OLD ADDRESS:}

Affix the address label from a recent issue of the journal here.

\section{NEW ADDRESS:}

Clearly print your new address here.

Name

Address

City/State/ZIP

\section{COPY AND MAIL THIS FORM TO:}

Elsevier Inc.

Subscription Customer Service

6277 Sea Harbor Dr

Orlando, FL 32887

\section{OR FAX TO:}

407-363-9661

OR E-mail:

elspcs@elsevier.com
OR PHONE:

800-654-2452

Outside the U.S., call

407-345-4000 